\title{
RENAL ARTERY THROMBOEMBOLISM FOLLOWED BY RENAL INFARCTION: A RARE CAUSE OF ACUTE FLANK PAIN, MIMICKING APPENDICITIS
}

\author{
Irena Šidiškienè $\dot{1}^{1}$ Žilvinas Barauskas ${ }^{2}$, Lina Minkevičiūtė $\dot{2}^{2}$ \\ ${ }^{1}$ Diagnostical Unit of Internal disease, Kaunas Clinical Hospital, Lithuania, \\ ${ }^{2}$ Faculty of Medicine, Medical Academy, Lithuanian University of Health Sciences
}

Key words: renal artery thromboembolism, atrial fibrillation, flank pain, appendicitis

\begin{abstract}
Summary
Renal artery thromboembolism (RATE) is a rare and serious condition, that is often hard to diagnose. It is very important for any physician to have in mind this pathology with unexplained flank pain, specially in patients with risk factors for this condition. Renal artery thromboembolism can cause partial or total renal infarction (RI), so early diagnostic and adequate treatment is necessary.Materials and Methods: We present a case report in elderly woman with risk factors for peripheral thromboembolism. A review of articles was done with intention to discuss this case, including common presenting symptoms, risk factors, diagnostic particularities, treatment options and complications, prevention. Conclusions: In a presence of symptoms - localised flank pain, nausea, vomiting and elevated $\mathrm{C}$ - reactive protein, white blood cells, creatinine, d- dimers - contrast enhanced CT scan should be performed as soon as possible. Anticoagulation therapy is thought to be the safest treatment strategy. Unfractioned heparine, if possible, can be replaced by low mass weight heparin in order to prevent anticoagulation therapy complications. To prevent embolic complications of AF - warfarine therapy can be replaced by rivaroxaban therapy.
\end{abstract}

\section{Introduction}

Renal artery thromboembolism is a rare condition, that is hard to diagnose, due to the nonspecific clinical manifestation. It accounts for $2 \%$ of peripheral thromboembolism events. Many cases of acute renal artery occlusion occur in a present of thromboembolic events, blunt abdominal trauma, hypercoagulable conditions or are unknown etiology. Howe- ver, the most common cause of RI is atrial fibrillation (AF) - $64 \%$ of published cases [1]. There were $0.004 \%-0.007 \%$ incidence of RI in emergency department according to some studies [2,3]. Clinical symptoms of RI varies, but the most common are localised pain, fever, nausea, vomiting and hematuria $[4,5]$. Also,it is known, that cancer can have influence on thromboembolic events because of hypercoagulable state and the prothrombotic effects of it's treatment, but usually it occurs in vein system $[4,6]$.

We present a case report of 83 years old women with chronical AF and breast cancer. The patient was hospitalised with unexplained pain in pelvic area with suspected appendicitis.

\section{Case presentation}

In November 2017, a 83 year old female was admitted to the emergency room (ER) because of nausea, vomiting and constant right flank pain, which at first was covering the entire abdominal area, then after 12 hours localised at the right flank ( 8 points of VAS).

Her medical history included breast cancer, three ischaemic strokes few years ago and chronical atrial fibrillation, essential hypertension. She was taking: Tamoxifen $20 \mathrm{mg} /$ day, Digoxin $0.25 \mathrm{mg} /$ day, Metoprolol $100 \mathrm{mg}$ /day, Isosorbidedinitrate $20 \mathrm{mg} /$ day and vit. $\mathrm{K}$ antagonist $2,5-5 \mathrm{mg} /$ day, which dose depended on International normalized ratio (INR). Nonsmoker.

Patient physical examination showed subfebrile body temperature $-37.4^{\circ} \mathrm{C}$, blood pressure of $148 / 80 \mathrm{mmHg}$ and heart rate of 82 beats/minute. The auscultation revealed nonregular heart beats. There was no tenderness in abdominal area, but painful palpation in the right flank. Jordan symptom negative. Other systems were unremarkable.

Laboratory tests revealed a white blood cell count 22.6 $\times 10^{9} / 1$ which has decreased after four days till $11.5 \times 10^{9} / 1$, erythrocytes $4.3 \times 10^{9} / 1$, haemoglobin $130 \mathrm{~g} / \mathrm{l}$, platelets 172 
$\times 10^{9} / 1$. C-reactive protein rised from $7.5 \mathrm{mg} / 1$ on the first day to $60.2 \mathrm{mg} / \mathrm{l}$ two days later. Potassium all of the hospitaliation time was in the normal range from 3.7 till $4.7 \mathrm{mmol} / \mathrm{l}$, but urea was elevated to $10.8 \mathrm{mmol} / \mathrm{l}$. Creatinine has reached the peak at fourth day of hospitalisation $-135.8 \mu \mathrm{mol} / 1$, in the end of treatment it has decreased $117.3 \mu \mathrm{mol} / 1$. Troponin I was increased to $0.126 \mu \mathrm{g} / 1$ on hospitalisation date, in the second day had reached $1.18 \mu \mathrm{g} / \mathrm{l}$ and eventually dropped down to $0.016 \mu \mathrm{g} / 1$ few days later. D-dimers was slightly elevated till $1,18 \mu \mathrm{g} / \mathrm{ml}$. During hospitalisation, INR was in normal range 2.3-2.2-1.5, Prothrombin time (PT) - $24 \%$. Before RATE, the patient had not reached therapeutic INR interval several times.

Liver function was insignificantly increased - ALT $62 \mathrm{U} / \mathrm{L}$, AST $82 \mathrm{U} / \mathrm{L}$. P-amylase was $24 \mathrm{U} / \mathrm{I}$, diagnosis of acute pancreatitis was rejected. Urinalysis was positive for red blood cells ( 50 cells $/ \mu \mathrm{L})$ and leukocytes ( 500 cells $/ \mu \mathrm{L})$, protein - negative, bacteries - positive, nitrite - negative urinal infection and pyelonephritis was excluded. The ECG showed an abnormal heart rhythm: atrial fibrillation -139 beats per minute with $\mathrm{T}$ inversion in $\mathrm{V}_{2}, \mathrm{~V}_{3}, \mathrm{~V}_{4}, \mathrm{~V}_{5}$ chest leads.

Firstly, infectious disease of unknown etiology was suspected and denied after laboratory tests results came. Then patient was transferred to surgical departament for farther investigation and treatment of acute abdominal pain. The patient was consulted by surgeon and gyneacologist. Later was perfomed abdominal ultrasound, which identified freeflowing stretch of liquid in the lower right abdominal area, about $1.1 \mathrm{~cm}$ thickness, the appendix was not visualised. Ultrasound did not show any renal abnormalities, so surgeons diagnosed acute appendicitis.

In surgery department patient was treated with drotaverin $80 \mathrm{mg} / 4 \mathrm{ml}$, ketoprophen $100 \mathrm{mg} / 2 \mathrm{ml}$ and metoclopramid $10 \mathrm{mg} / 2 \mathrm{ml}$ intramusculous injections and intravenous $0.9 \%$ $500 \mathrm{ml}$ sodium chloride.

Because of chronical AF, patient was transferred to intensive care unit (ICU) for preoperative preparation. As patient still remained symptomatic, a contrast-enhanced CT scan was performed in order to identify the etiology of pain localised on the right flank. D-dimers was increased to $1,18 \mu \mathrm{mol} / 1$ at that moment. Artery thrombosis was suspected. The CT scan showed right renal artery contrasting deffect $(0.6 \times 0.5 \times 2.1 \mathrm{~cm}$ floating thromb) followed by renal infarction signs - hypodential DI, not accumulating contrast in the inferior pole of the kidney (Figure 1). Additionally, the CT scan revealed some fluid in the pleural cavity: in the right cavity $1.1 \mathrm{~cm}$, in the left $-0.7 \mathrm{~cm}$ thickness and $0.4 \mathrm{~cm}$ thickness stretch of liquid near liver.

The echocardiography revealed ejection fraction $48 \%$, $\mathrm{I}^{\circ} \mathrm{MV}, \mathrm{AoV}, \mathrm{TV}$ regurgitations. Dilation of heart chambers or thrombi was not detected.
The diagnosis of renal artery thromboembolism with acute renal infarction was made. Thrombolysis or thromboaspiration was declined because of additional procedure risk. The patient was treated with heparin $1000 \mathrm{VV} /$ hour, following on APTT.

After 2 days in ICU an improvement of patient general status was noticed, so she was transferred to department of Internal medicine, where anticoagulation therapy was continued with heparin (50000VV overall). After 5 days of treatment with heparin, it was replaced byfraxiparin $0.6 \mathrm{ml} \mathrm{x}$ $2 / \mathrm{d}(10,8 \mathrm{ml}$ overall $)$ for 9 days, then fraxiparin was replaced by rivaroxaban $15 \mathrm{mg} \times 1 / \mathrm{d}$ (45mg overall) for 3 days.

During anticoagulation therapy, patient bleed from gastrointestinal tract. Fibroesophago- gastroduodenoscopy was performed and shown few hemorrhagic erosions in stomach. Hemoglobin was decreased to $86 \mathrm{~g} / \mathrm{l}$. After examination two units of erithrocyte mass transfusion was done, because of tissue hypoxia.

Eventually, abdominal pain have disappeared, signs of kidney supuration or other complications have not been observed. The renal function partially recovered and the serum creatinine was $117 \mu \mathrm{mol} / 1$ in the end of the treatment. The patient after discharge was recomended to continue the treatment with rivaroxaban, metoprolol, tamoxifen and omeprosol and was suggested to perform a renal ultrasound after a month. From that time till now, patient had not expirienced any anticoagulation therapy complications.

\section{Discussion}

Renal artery thromboembolism is a rare condition, that is hard to diagnose, due to the nonspecific clinical manifestation. It accounts for $2 \%$ of peripheral thromboembo-

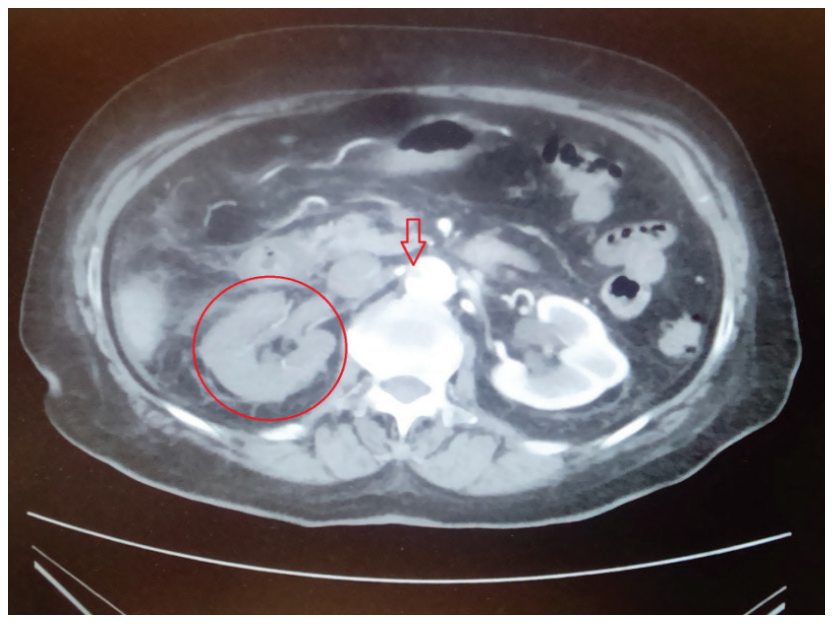

Figure 1. Enhanced CT scan - right renal artery contrasting deffect with noncontrasting right kidney 
lism events. Other localisation includes aorta (7\%), pelvic arteries $(9 \%)$, mesenteric arteries (29\%), upper and lower extremities (61\%) [7].

Clinical symptoms usually varies and can mimic nephrolithiasis, pyelonephritis, appendicitis or any other acute abdomen cause, but mostly it consists of localised pain (89.4\%), nausea/vomiting (43.8\%) and fever (26.8\%). Laboratory tests mostly shows elevated lactate dehydrogenase $(92.1 \%)$, C-reactive protein $(75.4 \%)$, white blood cells $(72.3 \%)$, creatinine $(42.7 \%)$, proteinuria (58.1\%) and hematuria (53.2\%) [8]. Our patient was hospitalised with acute flank pain, nausea and vomiting. Laboratory results showed slightly elevated alanine transaminase and asparagine transaminase. C-reactive protein and white blood cell count also were elevated. Troponin I increasing was secondary, because of thromboembolic complication and stressful situation. D -dimers was slightly increased. There were microhematuria and leucocituria without proteinuria.

Many cases of acute renal artery occlusion occur in a present of thromboembolic events, blunt abdominal trauma, hypercoagulable conditions or are unknown etiology. However, the most common cause of RATE and RI is AF - $64 \%$ of published cases [1]. Our patient also has cancer and is taking hormone therapy with tamoxyfen, which is known that can lead to hypercoagulation in circulation system [9]. Thromboembolic events are common side effects (including deep vein thrombosis, microvascular thrombosis and pulmonary embolism) [10]. It was observed, that patients who received adjuvant therapy with nonsteroid estrogen antagonists for breast cancer had a $5.4 \%$ frequency of thromboembolic complications more than those who have not. The combination of chemotherapy with tamoxifen was associated with more venous and arterial thromboembolic complications than using only a chemotherapy in premenopausal patients [11]. Other risk factors includes rheumatic heart disease, dilated cardiomyopathy, endocarditis [8]. Our patient had chronical $\mathrm{AF}$ and hypercoagulable state, treated by warfarin. However, patient had not reached therapeutic INR interval several times before, so ishaemic stroke years ago and RATE this time could be resulted by subtherapeutic INR.

Renal infarction, as a result of RATE, based on clinical view in imaging tools, can be devided in total and partial. [5]. According to fourty - four cases study - the most accurate diagnostic methods of RI are angiography (100\% accuracy), renal isotope scan ( $97 \%$ accuracy), contrast-enhanced computed tomography (CT scan) (80\% accuracy). Ultrasound was the least informative (11\% accuracy) [12]. Ultrasound and contrast enhanced CT scan was used in our patient. The first diagnostic method showed inflammation signs in the right lower quadrant, near appendix. But appendix was not visualised. Eventually CT scan was performed. It showed right renal artery contrasting defect followed by right renal lower pole hipodensity - ischaemia sign. Contrast enhanced CT scan was the most popular diagnostic tool in most RI cases [8]. According to literature, wedge - shaped noncontrasting, lower density peripheral areas with cortical rim sign was seen in most CT scans $[12,13]$.

RATE treatment can be divided into intravenous, oral anticoagulation, thrombolytic therapy, thrombectomy or renal angioplasty $[8,12]$. However, the most common treatment options for RATE followed by RI were unfractioned and low molecule mass heparins, warfarin ( $82.2 \%$ cases). Conservative treatment methods is thought to be much safier than invasive techniques in some cases. It is due to greater risk of contrast nephrotoxicity or additional invasive methodics during the procedure. Invasive techniques are proper in situations, when urgent and aggressive intervention is needed to ensure residual renal function in patients with function impairment or if only one kidney is left [8]. The treatment strategy mostly depends on the scale of affection and renal function impairment. In our case, the risk of invasive treatment strategy was evaluated and patient received anticoagulation therapy with unfractioned heparin, which, was replaced by fraxiparine and later by rivaroxaban. During the treatment with anticoaguliants, the patient bled from gastrointestinal tract, so erythrocyte mass transfusion was done in order to correct blood loss. According to literature, the major complication of anticoagulation therapy is bleeding. It is known, that low mass weight heparin is associated with fewer bleeding risks in compare to unfractioned heparin [14]. Metaanalyses support the inference that low mass weight heparin does not result in an increased risk of major bleeding compared with unfractionated heparin [15].

RATE and RI prevention is closely associated with adequate treatment strategy. There is evidence, that not reaching therapeutic INR interval can lead to thromboembolic events or even death. According to danish nationwide cohort study, the majority of thromboembolic events occurred during subtherapeutic INR and after warfarin interruption, independently of reasons for interruption [16]. For better and much comfortable anticoagulation therapy control, rivaroxaban is much more recommended to use than warfarin [17].

\section{Conclusions}

Renal artery thromboembolism is a rare condition, that can mimic any other acute abdomen cause with nonspecific clinical manifestation. In a presence of symptoms triad - localised flank pain, nausea, vomiting and elevated $\mathrm{C}$ - reactive protein, white blood cells, creatinine, d- dimers - contrast enhanced CT scan should be performed as soon as possible. Treatment option should be chosen depending on renal function and patient overall health status: for elder and non- 
complicated patients - anticoagulation therapy is thought to be the safest treatment strategy. Unfractioned heparine, if possible, could be replaced by low mass weight heparin in order to prevent anticoagulation therapy complications. To prevent embolic complications of AF - warfarine therapy can be replaced by rivaroxaban therapy. In our clinical case rivaroxaban was chosen because of bleeding from gastointestinal tract. This choice was much more safier and comfortable to control for our patient.

Conflicts of Interest: the authors declare no conflict of interest.

\section{References}

1. Bourgault M, Grimbert P, Verret C, Pourrat J, Herody M, Halimi J. et al. Acute renal infarction: a case series. Clinical Journal of the American Society of Nephrology 2012; 8(3),392-398. https://doi.org/10.2215/CJN.05570612

2. Huang C, Lo H, Huang H, Kao W, Yen D, Wang L. et al. ED presentations of acute renal infarction. The American Journal of Emergency Medicine 2007; 25(2), 164-169. https://doi.org/10.1016/j.ajem.2006.06.010

3. Domanovits H, Paulis M, Nikfardjam M, Meron G, Kürkciyan I, Bankier A. et al. Acute renal infarction: clinical characteristics of 17 patients. Medicine 1999; 78(6):386-394.

https://doi.org/10.1097/00005792-199911000-00004

4. Jurubita R, Obrisca B, Ismail G. A rare cause of acute kidney injury in a female patient with breast cancer presenting as renal colic. Case Reports in Nephrology 2016; 2016(9565873):4. https://doi.org/10.1155/2016/9565873

5. Chu P, Wei Y, Huang J, Chen S, Chu T, Wu K. Clinical characteristics of patients with segmental renal infarction. Nephrology 2006; 11(4):336-340. https://doi.org/10.1111/j.1440-1797.2006.00586.x

6. Van de Velde C, Rea D, Seynaeve C, Putter H, Hasenburg A, Vannetzel J. et al. Adjuvant tamoxifen and exemestane in early breast cancer (TEAM): a randomised phase 3 trial. Lancet 2011; 377(9762):321-331.

https://doi.org/10.1016/S0140-6736(10)62312-4

7. Frost L, Engholm G, Johnsen S. et al. Incident thromboembolism in the aorta and the renal, mesenteric, pelvic, and extremity arteries after discharge from the hospital with a diagnosis of atrial fibrillation. Arch Intern Med 2001; 161(2): 272-276. https://doi.org/10.1001/archinte.161.2.272

8. Huang H, Hsu C, Chen K. Acute renal artery embolism: a case report and literature review. General Medicine: Open Access 2016; 04(03):1-4. https://doi.org/10.4172/2327-5146.1000245

9. Caine G, Stonelake P, Lip G, Kehoe S. The hypercoagulable state of malignancy: pathogenesis and current debate. Neoplasia 2002; 4(6):465-473.

https://doi.org/10.1038/sj.neo.7900263
10. Tamoxifen 20mg Film-Coated Tablets - Summary of Product Characteristics (SmPC) - (eMC). Medicines.org.uk. Available online: https://www.medicines.org.uk/emc/product/2248/smpc (accessed on 19 February 2019).

11. Saphner T, Tormey D, Gray R. Venous and arterial thrombosis in patients who received adjuvant therapy for breast cancer. Journal of Clinical Oncology 1991; 9(2):286-294.

https://doi.org/10.1200/JCO.1991.9.2.286

12. Hazanov N, Somin M, Attali M, Beilinson N, Thaler M, Mouallem M. et al. Acute renal embolism. Medicine 2004; 83(5):292-299.

https://doi.org/10.1097/01.md.0000141097.08000.99

13. Suzer O, Shirkhoda A, Jafri S, Madrazo B, Bis K, Mastromatteo J. CT features of renal infarction. European Journal of Radiology 2002; 44(1):59-64. https://doi.org/10.1016/S0720-048X(01)00476-4

14. Mulloy B, Barrowcliffe T, Gray E. Heparin and low-molecular-weight heparin. Thrombosis and Haemostasis 2008; 99(11):807-818.

https://doi.org/10.1160/TH08-01-0032

15. Levine MN, Raskob G, Landefeld S, Kearon C. Hemorrhagic complications of anticoagulant treatment. Chest 2001; 119(1):108-21.

https://doi.org/10.1378/chest.119.1_suppl.108S

16. Raunsø, J, Selmer C, Olesen JB, Charlot MG, Olsen A-MS, Bretler D-M. et al. Increased short-term risk of thromboembolism or death after interruption of warfarin treatment in patients with atrial fibrillation. European Heart Journal 2011; 33(15):1886-92.

https://doi.org/10.1093/eurheartj/ehr454

17. Coleman CI, Haas S, Turpie AG, Kuhls S, Hess S, Evers T. et al. Impact of switching from a vitamin $\mathrm{K}$ antagonist to rivaroxaban on satisfaction with anticoagulation therapy: the XANTUSACTS substudy. Clinical Cardiology 2016; 39(10):565-9. https://doi.org/10.1002/clc.22565

\section{INKSTU ARTERIJOS TROMBOEMBOLIJA IR JOS SUKELTAS INKSTO INFARKTAS: APENDICITĄ IMITUOJANTIS ŠONO SKAUSMAS} I.Šidiškienė, Ž.Barauskas, L.Minkevičiūtė

Raktažodžiai: inkstų arterijos tromboembolija, prieširdžių virpejjimas, šono skausmas, apendicitas.

Santrauka

Inkstų arterijos tromboembolija (IATE) - reta ir rimta būklè, dažnai sukelianti diagnostinių problemų. Kiekvienas gydytojas, savo darbe susidūręs su sunkiai paaiškinamu šono skausmu, ypač esant rizikos veiksniams, turètų prisiminti šią patologiją. IATE gali sukelti dalinị arba visišką inkstų infarktą, todèl būtina ankstyva diagnostika bei adekvatus gydymas. Šiuo tikslu pristatome klinikinị atvejị bei literatūros apžvalgą, apimančią dažniausius IATE simptomus, rizikos veiksnius, diagnostikos bei gydymo ypatumus, prevenciją.

Adresas susirašinėti: bar.zilvinas@gmail.com Gauta 2019-05-08 